


\section{Article Artículo Paper Inclusió social i intervenció 4 socio-educativa mitjançant l'esport. L'experiència de les escoles esportives 613 de Burjassot}

\section{F. Xavier Uceda-} Maza $^{1}$

\section{María García}

\section{César Romero:}

Lúcia Martí-

nez-Martínez

\section{Cristina Montón}

\section{Resum}

En el següent article, es presenta la sistematització de l'experiència d'inclusió social desenvolupada des de l'entitat Escoles Esportives 613 Vivendes de Burjassot. Constitueix una experiència d'intervenció socio-educativa mitjançant l'esport en un context marcat per l'exclusió social.

El barri de les 613 Vivendes va ser construït l'any 1979 amb l'objectiu d'acabar amb el xabolisme de la perifèria de la ciutat de València; constituint-se amb el anys, en un exemple d'exclusió social associat al territori, on s'intensifiquen les desigualtats socio-espacials. Prompte, viure en el barri provoca un fort impacte en el comportament social, la qualitat de vida $\mathrm{i}$ les oportunitats de futur dels que viuen en ell. 
Les Escoles Esportives 613 Vivendes, sorgeixen l'any 1994 com a experiència de participació comunitària i de promoció de la convivència social, sent el seu instrument la promoció de l'esport base, recolzant-se en el voluntariat i en la participació social dels veïns. Després de tretze anys, hui és coneguda i reconeguda en el barri de les 613 Vivendes i en el municipi de Burjassot.

Lobjecte d'aquest article és la sistematització de la intervenció, ja que constitueix un exemple de bona pràctica de treball social comunitari per a la inclusió social mitjançant l'esport i la participació comunitària en l'àmbit local.

Paraules clau: Inclusió Social, Intervenció Comunitària, Barri Desfavorit, Participació Social, Esport, Treball Social.

\section{Resumen}

En el siguiente artículo, se presenta la sistematización de la experiencia de inclusión social desarrollada desde la entidad Escoles Esportives 613 Vivendes de Burjassot. Constituye una experiencia de intervención socio-educativa mediante el deporte en un contexto marcado por la exclusión social.

El barrio de las 613 Viviendas fue construido el año 1979 con el objetivo de acabar con el Chabolismo de la periferia de la ciudad de València, constituyéndose con el paso de los años, en un ejemplo de exclusión social asociado al territorio, donde se identifican las desigualdades socio espaciales. Pronto, vivir en el barrio provoca un fuerte impacto en el comportamiento social, la calidad de vida y las oportunidades de futuro de los que viven en el.

Les Escoles Esportives 613 Vivendes, surgen el año 1994 como experiencia de participación comunitaria y de promoción de la convivencia social, siendo su instrumento la promoción del deporte base, apoyándose en el voluntariado y en la participación social de los vecinos del barrio. Después de trece años, hoy es conocida y reconocida en el barrio de las 613 Viviendas y en el municipio de Burjassot. 
El objeto de este artículo es la sistematización de la intervención, ya que constituye un ejemplo de buena práctica de trabajo social comunitario para la inclusión social mediante el deporte y la participación comunitaria en el ámbito local.

Palabras clave: Inclusión social, Intervención Comunitaria, Barrio Desfavorecido, Participación Social, Deporte, Trabajo Social.

\begin{abstract}
The following article presents the systematization of an experiment in social inclusion carried out via the 613 Viviendas sports schools in Burjassot. The experiment involves a social-educational intervention through the medium of sport in a context of social exclusion.
\end{abstract}

The 613 Viviendas estate was built in 1979 to house people from the shanty towns that had sprung up on the outskirts of the city of Valencia. Over the years it became an example of social exclusion associated with a territory in which socio-spatial inequalities were intensifying. Living on the estate would soon have a strong impact on the social behaviour, quality of life and future opportunities of the residents.

The 613 Viviendas sports schools first appeared in 1994 as an attempt to encourage community participation and social harmony through the promotion of grassroots sport, relying on volunteer workers and social participation by residents. Today the scheme is well-known and appreciated on the 613 Viviendas estate and throughout the Burjassot council area.

The aim of this article is to systematize the intervention as it provides an example of good practice in community social work aimed at encouraging social inclusion through sport and community participation at a local level.

Keywords: Social inclusion, Community intervention, Disadvantaged neighbourhood, Social participation, Sport, Social work. 


\section{Introducció}

Les Escoles Esportives 613 Vivendes $^{6}$ és una entitat de caràcter social sense ànim de lucre, que treballa en el barri desfavorit de les 613 Vivendes de Burjassot (València). Un barri declarat d'acció preferent pel Decret 157/1988 del Consell de la Generalitat Valenciana. El Decret de Barris d'Acció Preferent és el marc d'actuació bàsic en el conjunt de territoris que presenten greus problemes d'exclusió social a la Comunitat Valenciana i son catalogat així per la Generalitat Valenciana.

L'entitat va ser creada l'any 1994, a partir de l'esforç conjunt de tres entitats (Associació de Veïns 613 Vivendes, Associació Civil “Manantial” i els Serveis Socials municipals) i un grup de joves, que pensaven que una de les formes de promocionar a la infancia de barris desfavorits era mitjançant la pràctica d'activitats esportives.

Des de llavors fins a l'actualitat, aquesta entitat ha procurat trencar les barreres de tipus social de rebuig que es creen al voltant dels barris desfavorits, treballant per la integració real i efectiva, a nivell social, relacional i local del Barri d'Acció Preferent 613 Vivendes 7.

L'objecte d'aquest article és la sistematització de la pràctica generada als darrers 13 anys, ja que constitueix un exemple de bona pràctica en el marc del treball social per a la inclusió social mitjançant l'esport. A continuació es fa referència als antecedents, és a dir als elements teòrics i de recerca que justifiquen aquesta pràctica.

\section{Antecedents: Els barris desfavorits i les activitats esportives com a mitjà d'inclusió social}

En la societat postmoderna, la vulnerabilitat i el risc d'exclusió atrapen a sectors més amplis de la societat; els riscos s'han ampliat i diversificat fent-nos més vulnerables en extensió i intensitat, en aquest sentit Castel (1997) assenyala que la societat actual és caracteritza per una zona de vulnerabilitat antesala de l'exclusió cada vegada major. Bourdieu (1999) caracteritza la vulnerabilitat com un estat permanent de precarité, inseguretat de

6. A continuació s'empraran les sigles EE.EE 613 per a denominar a las Escoles Esportives 613 Vivendes.

7. A continuació s'empraran les sigles BAP 613 per a referir-se al Barri d'Acció Preferent 613 Viviendes. 
nivell social, incertesa del futur i sentiment de no controlar el present que es combina amb una incapacitat de construir projeccions futures i actuar coherentment.

$\mathrm{El}$ territori introdueix desigualtats. Les seues característiques físiques $\mathrm{i}$, sobretot humanes (xarxes de transport, equipaments, usos del sòl, etc.), fan impossible la igualtat d'oportunitats real. El lloc de residència de cada persona i la forma en què experimenta o viu la seua realitat (determinada pel seu entorn), contribueix, junt amb altres factors, a explicar les diferències socials i les divergents trajectòries de vida de moltes persones, en particular els joves. Viure en barris sensibles marca les personalitats dels residents i els condueix a l'autoexclusió, condicionant les relacions socials amb la resta de residents de la ciutat que fugen d'aquests territoris per por als seus residents (Herin, 2008).

Són molts i diversos els col-lectius en situacions d'especial vulnerabilitat, i poques vegades constitueixen una prioritat visible de l'acció de govern. La infancia i l'adolescència vulnerable és un dels grups més invisibles i amb més dificultats per a fer-se amb el seu espai social (Pérez Cosín i Uceda-Maza, 2009). En una societat caracteritzada no sols per tenir grans grups exclosos o al marge, sinó pels extensos grups que viuen en la vulnerabilitat i que corren el risc de desplomar-se en l'exclusió; la qüestió a reflexionar és com a afecta la seua infancia i adolescència. En aquest sentit, Zarzuri (2000) revela que els factors de vulnerabilitat en els adolescents estan més relacionats amb les contingències vinculades a les causes que generen el risc (residir en un barri amb elevada taxa de desocupació i ociositat), que amb el risc en si mateix (la desocupació / l'ociositat). Des d'aquesta perspectiva, el temps d'exposició al risc configurarà el grau de vulnerabilitat a què s'ha sotmès un individu, sobre el qual l'exclusió dissenyarà el seu particular pla de desgast.

L'estudi de l'exclusió social vinculada a la segregació social i la seua relació amb la vida comunitària és objecte d'estudi de les ciències socials. En les darreres dècades s'ha evidenciat un major interès i preocupació cap a l'exclusió social en general, i cap a l'exclusió social juvenil en particular, ja que lluny de desaparèixer del mapa de les ciutats europees, aquesta s'ha vist accentuada, fins al punt de manifestar-se a través de diverses revoltes juvenils en distintes ciutats com París (novembre 2005) i Londres (agost 2011).

A Europa l'increment del risc de vulnerabilitat així com l'emergència de marginalitat urbana no han suposat la guetització de determinats barris, sinó la diferenciació social 
i concentració de desavantatge social en determinades parts de la ciutat, amb alt predomini en els barris perifèrics (Paugam, 2007 i Wacquant, 2008). L'evidència de processos de segregació urbana i residencial sumats a indicis de segregació escolar, aguditzen les divisions i les tensions etnicoracials que tenen lloc principalment en barris desfavorits. Els problemes de marginalitat urbana són un tema cada vegada més present en les agendes polítiques i socials ja que amenacen de ser problemes crònics i de qüestionar els modes tradicionals de ciutadania (Wacquant, 2007).

Coincidint amb aquest context d'intensificació de les desigualtats socioespacials, i per tant d'un augment del nombre d'àrees urbanes desfavorides (Atkinson i Kintrea, 2001), el debat sobre els efectes del barri ha suscitat un interès que va in crecendo. Els treballs empírics de Brooks-Gunn, et al. (1993) assenyalen que viure en un determinat barri impacta sobre el comportament social, la qualitat de vida i les oportunitats de futur dels que viuen en ell, fent especial insistència en la influència negativa, especialment on hi ha importants deficiències en equipaments i serveis socials dirigits a la ciutadania (Wilson, 1987; Jencks i Mayer, 1990 i Musterd et al., 2006). El territori es configura, per tant, com un element fonamental per a explicar l'exclusió social. L'anàlisi del mateix és complex, com el propi espai, a causa de la multitud d'interrelacions existents, sinergies i ralentitzacions, per tant l'enfocament interdisciplinari es configura com el més adequat.

La realització de manera dirigida de l'Activitat Esportiva en els barris, és un fenomen recent a la història de l'Educació, que té el seu origen després de la II Guerra Mundial a França, quan la població destrossada a tots els nivells pel conflicte bèl·lic de l'ocupació nazi, precisava d'alguna eina per eixir endavant. Sorgeixen així els moviments populars internacionals d'educació, que a l'Estat Espanyol arriben a 1959 com una estratègia de lluita contra els efectes socials generats per una situació de falta de llibertats en comunitats i territoris de la nostra geografia i com una eina d'intervenció socioeducativa (Úcar, 2002).

En els darrers vint anys, les polítiques socials dels països amb sistemes de benestar més complexos han incorporat l'esport per a intervenir sobre les àrees tradicionals de l'acció social o sobre les manifestacions més recents de l'exclusió social (Santos et al., 2004). Planteja Subirats et al. (2010) que parlar d'inclusió social és parlar de ciutadania. La inclusió social i la ciutadania operen amb lògiques distintes, però estretament vinculades, $\mathrm{i}$ una és condició i possibilitat de l'altra. En els seus encreuaments, limitacions, dinàmiques 
es produeix la inclusió social. Així mateix, després d'analitzar diferents experiències d'intervenció social amb col·lectius conclou que els tres elements fonamentals que constitueixen la clau de la intervenció són: acollir, acompanyar i construir autonomia. Marchioni (1989), considera que la intervenció comunitària és la metodologia del Treball Social que millor permet treballar en la prevenció de l'exclusió social així com en inici de processos d'inclusió social.

D’una forma innovadora, l'activitat física i l'esport forma part d'eixa tradició d'acció comunitària implantada als nostres barris per generar teixit social a partir de la dècada dels 60 per organitzacions i professionals del treball social:

“...L'activitat física i l'esport correctament planificades, amb una metodologia específica i seguint la idea d'educació física centrada en la promoció de valors pot contribuir a la prevenció de conductes antisocials i a la millora de la qualitat de vida i del benestar personal i social d'estes poblacions, generant una alternativa positiva en les seues vides..." (Jiménez et al., 2005:14)

Muñoz (2011) a partir d'una sistematització dels estudis sobre el tema realitzats per altres autors, classifica els beneficis de l'esport a escala individual i a escala grupal: a) Individual: proveeix l'oportunitat d'adquirir habilitats físiques i esportives; augmenta l'autoestima; permet el reconeixement de les limitacions pròpies; avalua destreses i aptituds permetent als participants conèixer millor el seu cos; dóna l'oportunitat de responsabilitzar-se de la pròpia salut; ocupació del temps lliure; acceptació de regles i normes; transmissió de valors educatius (esforç, perseverança, esperit d'equip); ofereix models socials dignes d'imitació a través de la funció heroica (el mite de l'heroi esportiu, del patiment, de l'abnegació); reforça la identitat personal; propicia oportunitats d'ocupació i b) Grupal: és un mitjà d'inserció, de socialització i accés a la ciutadania; dóna l'ocasió de conèixer i comunicar-se amb gent nova, és un lloc de trobada, d'acceptació de diferències; tant en les pràctiques més regulades com en aquelles més informals, l'esport propícia la interacció entre els participants, la creativitat i el desenvolupament de la personalitat; proporciona locasió al grup de construir les seues experiències i de reforçar la sociabilitat.

La intervenció amb collectius desfavorits per mitjà de l'activitat física i l'esport, ha de tenir com a objectiu fonamental el desenvolupament personal i social per damunt de 
millorar les seues habilitats físiques; cercant un desenvolupament amb i no per a la pràctica esportiva. Les activitats fisicoesportives es converteixen en un mitjà per a aconseguir els objectius a nivell social no un fi en si mateix (Pardo, 2008).

Hellison (1995) assenyala que la pràctica esportiva amb adolescents en situació de risc permet adquirir i desenvolupar valors com l'esforç i l'autogestió propis del benestar i el desenvolupament personal, així com respecte als sentiments i als drets dels altres i capacitat per escoltar i posar-se en el lloc dels altres més vinculats a la integració social. De fet la Comissió Europea per a l'esport, afirma que aquest constitueix, un dels àmbits més importants de l'activitat comunitària:

"L'esport constitueix un instrument adequat per a promoure una societat més inclusiva, per a lluitar contra la intolerància i el racisme, la violència, l'abús de l'alcohol o l'ús d'estupefaents; l'esport pot contribuir a la integració de les persones excloses del mercat laboral"

Mitjançant el programa europeu "Youth in Action", amb el nom de "Training Course Streetwise" s'investigà aquests pressupostos en 12 països europeus i es van concloure que l'esport és una eina eficaç per a treballar amb col·lectius exclosos (Fernández Gavira, 2008).

Però no hem d'oblidar que l'esport també té uns límits a tindre en compte tant per les persones que l'utilitzen per educar com per les que el reben. Segons planteja Maza et al (2009) al Pla integral per l'activitat física i l'esport, existeixen uns límits respecte a l'esport i la integració de col·lectius en risc d'exclusió: a) Projectes que a la seua dinàmica interna i externa fomenten més la deportivització que la integració, de forma que es torna a donar l'exclusió dels que no tenen bones qualitats esportives, b) Projectes esportius que atribueixen a l'esport un paper rehabilitador sense límits de les persones que presenten un tipus de desviació social, c) Projectes o esdeveniments esportius on reben més importància els organitzadors que els organitzats i d) Projectes que esdevenen en un apadrinament de les persones a les que van dirigits. 


\section{Metodologia i Context Territorial}

Aquest treball es fruït d'un procés de sistematització. Aquesta permet la recuperació d'una experiència de la pràctica i mitjançant un procés de diàleg permanent amb la teoria produir coneixement, per tant és una metodologia de recerca molt utilitzada en disciplines com el treball; molt pròpia dels moviments d'educació popular i forma part de les estratègies de produir coneixement des de la Investigació-Acció-Participació (Leal, 2009).

Des d'un procés metodològic concebut des de la sistematització cal partir del present, a partir d'allò que fem, dels problemes, els interrogants, els desafiaments i els qüestionaments, les necessitats i les contradiccions que es tenen en el moment actual i tenir una visió prospectiva de futur. És possible fer aquesta perquè l'entitat EE.EE 613 porta dinou anys treballant en un mateix context territorial i social, amb una mateixa finalitat i amb estratègies semblants.

Per aquest article, l' anàlisi ha constat de dues parts, una l'explotació de dades secundàries a partir de la anàlisi de les fonts documentals escrites de l'entitat (memòries anuals); i l'altra, entrevistes amb la Junta Directiva, monitors esportius i collaboradors de l'entitat; aportant una complementarietat entre dades quantitatius i qualitatius. Així mateix els autors d'aquest article han sigut en diferents moments col-laboradors de l'entitat.

E1 BAP 613 es construeix a finals dels anys setanta com resultat del disseny d'una sèrie d'estratègies estatals per a acabar amb el xabolisme, barraquisme i habitatges d'autoconstrucció. Un barri compost íntegrament per habitatge social, ubicat en la zona nordoest de Burjassot, ciutat dormitori enclavada en l'àrea metropolitana de València. El barri es pobla en un temps molt breu amb persones sense vincles, sense sentit de pertinença a la comunitat, desconegudes, procedents de zones molt diverses geogràficament; però tenint en comú les seues dificultats per a l'accés a un habitatge normalitzat i la seua precarietat econòmica, la qual cosa ens indica que tipus de comunitat artificial es va a conformar en breu temps (Monje i Uceda, 2003).

Entre les diverses problemàtiques sorgides en el barri podem ressaltar la degradació contínua i permanent del mateix, fenòmens propis de finals dels anys 80 , com són els alts índexs de consum i venda de droga que es realitza dins del barri i que afecta la població infanto-juvenil, tenint com a conseqüència l'increment desmesurat de la delinqüència ju- 
venil. Evidentment aquesta situació també afecta el conjunt del municipi de Burjassot, on cada vegada més es produeix un sentiment d'estigmatització i de rebuig del conjunt dels veïns de les 613 vivendes; realitzant-se manifestacions de comerciants i veïns per l'increment progressiu de la delinqüència i de la degradació social existent, exigint a les autoritats municipals la seua intervenció amb caràcter urgent.

En l'actualitat, el barri disposa d'un cens de 2.139 veïns i concentra greus problemes d'exclusió social, desocupació, desestructuració familiar, drogues i delinqüència juvenil. La població menor de 30 anys representa el 46.5 \% de la població, 10 punts per damunt del percentatge corresponent municipal.

E1 BAP 613 és una àrea d'important concentració de persones pertanyents al poble gitano, al voltant del $25 \%$ de les persones hi residents pertanyen a aquest col-lectiu. Pel que fa a la població immigrant, representen un poc més del 7 \% de la població del barri.

Les últimes dades facilitades sobre la taxa d'atur del barri (2013), es trobava en el $51.7 \%, 30$ punts per damunt de la taxa que eixe any tenia Burjassot; i una taxa d'activitat del 28.6 \% i d'inactivitat del 40.7\%. Taxes que han anat agreujant-se els darrers anys per la crisi econòmica que vivint, $\mathrm{i}$ que ha fet augmentar la pobresa i la desigualtat, de fet des què es disposen de dades no s'havia registrat un creixement tan alt de la desigualtat (Foessa, $2013)^{8}$. Aquest barri és precisament un context territorial on la crisi ha actuat amb major virulència, empobrint cada vegada més als seus veïns.

A nivell educatiu, el BAP 613 presenta problemes severs d'absentisme escolar, abandonament prematur dels estudis i fracàs escolar, sent els nivells educatius en el barri realment baixos ja que un 67 \% de la població no ha finalitzat l'educació bàsica (EGB o ESO). L'any 2013, el 52.2 \% de l'absentisme escolar del municipi es trobava en el BAP 613.

Respecte a la delinqüència juvenil, hem de destacar que des de que es va crear el programa mesures judicials en medi obert ${ }^{9}$ i fins l'any 2005, el pes d'aquest programa mu-

8. L'índex de Gini ha augmentat gairebé un 10\%, mentre que la diferencia entre la renda del percentil 80 i el percentil 20 ha crescut un 30\%. Això confirma les diferències entre extrems de la distribució de la renda ja que millora la de les llars més riques i empitjora la de les llars més pobres (Foessa, 2013).

9. E1 Programa de Mesures Judicials en Medi Obert és un programa que intervé amb els adolescents i joves als que se'ls ha imposat una mesura judicial segons contempla la 1lei 5/2000 de responsabilitat penal del menor. 
nicipal se situava al BAP 613, tenint entre un $60 \%$ i $70 \%$ dels menors derivats al programa amb residència al barri. Aquesta situació va començar a minvar a partir de l'any 2006 per diversos factors: la intervenció comunitària al barri, increment de menors residents en altres barris del municipi, etc.; arribant l'any 2010 ser el 70\% dels menors de mesures judicials d'altres barris del municipi. No obstant, la prevalença d'adolescents delinqüents continua sent major al barri (l'any 2010 la prevalença de delictes al BAP 613 és d'un 7.22 $\%$, front un $1.94 \%$ de la resta del municipi).

A causa de les problemàtiques existents en el barri, de les quals hem reflectit algunes pinzellades, es va iniciar un procés d'intervenció comunitària des dels Serveis Socials municipals amb la dotació d'importants recursos: Unitat de Treball Social de Zona "613 Vivendes", Centre de Dia per a menors, Centre d'atenció a la Infancia, ludoteques, Programa de Mesures Judicials al Medi Obert. Així mateix s'han desenvolupat des de l'Administració Pública diversos projectes en el barri per a combatre l'aïllament del mateix, millorar les seues condicions d'habitabilitat, afavorir la formació i inserció laboral i la integració en la resta del conjunt del municipi. Malgrat l'eliminació de les barreres arquitectòniques que separaven al barri de la resta de Burjassot, i la seua integració física en el municipi al BAP 613 contínua abundant el sentiment d'estigmatització i de rebuig, i manté moltes de les problemàtiques característiques dels barris desfavorits.

Sens dubte, el barri de les 613 "Vivendes" constitueix un laboratori social per a analitzar les polítiques i programes d'inclusió social desenvolupats per les administracions públiques i el tercer sector o projectes sorgits de la col·laboració entre ambdós institucions com el cas de les EE.EE “613 Vivendes”.

\section{Els eixos de la Inclusió Social i la Intervenció Comunitària en les Escoles Esportives 613 Vivendes}

E1 treball desenvolupat per les EE.EE “613 Vivendes” s'ubica en el tercer nivell d'acció social de Marchioni (1989), és a dir desenvolupant acció social amb la comunitat. És una experiència d'intervenció comunitària heretera de l'educació popular. Les seues estratègies d'intervenció sobre les quals es fonamenta i articula són: 


\section{Estratègia I. Metodologia d'intervenció amb els infants i adolescents.}

Els infants i adolescents amb què l'entitat treballa provenen principalment del BAP 613, molts d'ells derivats pels Serveis Socials municipals i els centres escolars. Són menors en situació de risc social, per la situació sociofamiliar, presentant problemes importants d'absentisme i abandonament escolar, retards maduratius, carències afectives i d'hàbits conductuals i higiènics, etc.

A les EE.EE 613 no es fa distinció entre nivells socials, econòmics, culturals, i ètnics. La pràctica esportiva permet treballar obertament valors com la solidaritat, el respecte per un mateix i pels altres, la tolerància, la camaraderia; i hàbits com la puntualitat, la responsabilitat i la higiene, etc. Es potència les actituds dels infants positives i es treballa per la modificació de les negatives. Mitjançant la pràctica esportiva, es genera resiliència en els infants i adolescents, capacitat de millorar el seu futur, ja que l'entrenament constant, la millora en les relacions i formes d'interactuar són reforçades positivament pels seus entrenadors millorant la seua percepció de si mateix.

L'esport és la porta per treballar amb les famílies des d'una perspectiva integral, ja que en els moments informals, en els entrenaments, partits, etc, es treballa amb la família la importància d'anar a l'escola, dels hàbits conductuals, higiènics, etc. Així mateix és una oportunitat per treballar en el grup d'iguals, ja que moltes de les actituds i comportaments estan vinculats al seu grup de socialització i la seua modificació implica generar en el grup altres pautes alternatives de socialització.

En aquest moment, l'esport que s'ha triat per fer aquesta intervenció amb els infants i adolescents del barri és el futbol sala. Al voltant d'aquest esport, , s'està intervenint amb un total de 120 infants i adolescents d'edats compreses entre 4 i 18 anys, distribuïts en equips de diferents categories que participen en diferents lligues d’àmbit local, provincial i autonòmic. Però per visualitzar millor la realitat de intervenció d' aquesta estratègia en l'any 2012, el nombre de menors i jóvens amb els que es treballa en aquesta línea, mostrem la taula 1 on es reflectix els diferents equips formats, les edats amb les que s'intervé i nombre de menors. 
Taula 1. Nombre d'infants i adolescents amb els que intervé les EE.EE. 613.

\begin{tabular}{|c|c|c|c|}
\hline CATEGORIA & EDAT & No EQUIPS & No MENORS \\
\hline QUERUBÍ & 4 i 5 anys & 1 & $\mathbf{1 4}$ \\
\hline PREBENJAMÍ & 6 i 7 anys & 1 & $\mathbf{1 2}$ \\
\hline BENJAMI & 8 i 9 anys & 2 & $\mathbf{2 0}$ \\
\hline ALEVI & 10 i 11 anys & 2 & $\mathbf{1 9}$ \\
\hline INFANTIL & 12 i 13 anys & 2 & $\mathbf{2 0}$ \\
\hline CADET & 14 i 15 anys & 1 & $\mathbf{9}$ \\
\hline JUVENIL & 16,17 i 18 anys & 1 & $\mathbf{1 7}$ \\
\hline FEMENÍ & De 12 fins 18 anys & 2 & 120 \\
\hline TOTAL & & 12 & \\
\hline
\end{tabular}

Font: elaboració pròpia a partir de les dades facilitades per l'associació EE.EE. 613 referents a l’any 2012.

Estratègia II. Promoció i formació del voluntariat que treballa amb els infants i adolescents.

“...El voluntariado en organizaciones deportivas ofrece numerosas oportunidades de educación no formal, algo que es necesario reconocer y mejorar. El deporte también ofrece actractivas posibilidades para el compromiso de los jóvenes y su participación en la sociedad, y puede tener un efecto beneficioso para ayudar a las personas a apartarse de la delicuencia..." (Libro blanco sobre el deporte, 2007: 7)

Atenet a l'afirmació del Llibre blanc sobre l'esport presentat per la Comissió de les Comunitats Europees, la promoció del voluntariat és un dels eixos fonamentals de la entitat. L'equip de voluntaris de les EE.EE. 613 està compost per un total de 20 membres distribuïts en dos blocs importants: junta directiva i entrenadors; com podem veure en el següent quadre. 
Quadre 1. Distribució dels voluntaris de les EE.EE. 613.

\begin{tabular}{|c|c|c|}
\hline VOLUNTARIS & NOMBRE & FUNCIONS \\
\hline JUNTA DIRECTIVA & 7 & Presa de decisions referents al funcionament de l'entitat. \\
\hline ENTRENADORS & 13 & $\begin{array}{l}\text { Preparació i desenvolupament de les activitats amb els } \\
\text { menors (entrenaments, partits, etc). Els entrenaments } \\
\text { són de dos a tres per categoria, i els partits, un o dos a la } \\
\text { setmana, depenent de la lliga i les altres competicions. }\end{array}$ \\
\hline $\begin{array}{c}\text { ALTRES } \\
\text { COL·LABORADORS }\end{array}$ & 6 & $\begin{array}{l}\text { Col-laboració en les activitats de l'entitat, tasques } \\
\text { administratives, assessorament, etc. Són treballadors } \\
\text { socials, etc que fan suport fent-ne acompanyament a } \\
\text { l'entitat }\end{array}$ \\
\hline
\end{tabular}

Font: elaboració pròpia a partir de les dades facilitades per l'associació EE.EE. 613 referents a l'any 2012.

En el que respecta a la promoció del voluntariat, un dels criteris fonamentals de l'entitat és el treball mitjançant els veïns del propi barri, els quals han de prendre consciència de la seua realitat i decidir canviar-la. El procés de concientitzar-se no és només prendre consciència de quelcom ha de canviar, sinó que suposa també prendre una decisió que implica un compromís. Per això, és precís arribar a la consciència crítica, i només des d'aquesta, les persones cerquen les causes reals i les correlacions, i des d'ací no és possible fugir de les pròpies responsabilitats. S'educa en la capacitat de triar al posseir més d'un punt de vista de la seua situació, la seua forma de vida i el seu entorn. Així mateix, s'adquireix la capacitat de transformació d'aquelles coses que no són del seu grat, no els interessa o consideren negatives. (Freire, 2004 i 2005).

Per això, el voluntariat de les EE.EE 613 és un voluntariat principalment resident al barri, sensibilitzat amb la seua realitat més pròxima. Com podem veure, el $100 \%$ dels voluntaris que conformen la junta directiva, resideixen al BAP 613; i en el cas del entrenadors, un $77 \%$ pertanyen al barri, i l'altre 33 són veïns de Burjassot que viuen en els barris pròxims al BAP 613. A més, gran part d'ells, un $57 \%$ en el cas de la junta directiva i un 77 $\%$ en el cas dels entrenadors, són voluntaris que quan eren infants i adolescents també van pertànyer a les EE.EE. 613 i van jugar als seus equips. Per fer-nos una imatge més clara de l'equip de voluntaris que conformen l'entitat, en la següent taula es mostren algunes dades sobre la seua residència, situació, etc. 
Taula 2. Algunes dades dels voluntaris de les EE.EE. 613.

\begin{tabular}{c|c|c|c|c|c|}
\hline & $\begin{array}{c}\text { RESIDIXEN } \\
\text { AL BAP 613 }\end{array}$ & $\begin{array}{c}\text { ETNIA } \\
\text { GITANA }\end{array}$ & $\begin{array}{c}\text { PROMOCIÓ } \\
\text { DE LES } \\
\text { EE.EE 613 }\end{array}$ & $\begin{array}{c}\text { SENSE } \\
\text { TREBALL }\end{array}$ & $\begin{array}{c}\text { PROBLEMIES } \\
\text { AMB LA } \\
\text { JUSTÍCIA }\end{array}$ \\
$\begin{array}{c}\text { JUNTA } \\
\text { DIRECTIVA }\end{array}$ & $100 \%$ & $14 \%$ & $57 \%$ & $43 \%$ & $29 \%$ \\
\hline ENTRENADORS & $77 \%$ & $23 \%$ & $77 \%$ & $39 \%$ & $39 \%$ \\
\hline
\end{tabular}

Font: elaboració pròpia a partir de les dades facilitades per l’associació EE.EE. 613 (any 2012).

Però es tracta d'un equip de voluntaris de nivells educatius-formatius mig-baix (majoritàriament sense haver conclòs els estudis primaris), que dificulta la seua participació en processos formatius normalitzats. Tan sols un $14 \%$ de la junta directiva y un $15 \%$ dels entrenadors han tret el graduat escolar i de vegades a partir de col·laborar a l'entitat, ja que tot espai de relació és espai d'intervenció social.

Taula 3. Nivell d'estudis dels voluntaris de les EE.EE. 613.

\begin{tabular}{|c|c|c|c|}
\hline & Sense estudis & $\begin{array}{c}\text { Certificat } \\
\text { d'escolaritat }\end{array}$ & Graduat escolar \\
\hline JUNTA DIRECTIVA & $57 \%$ & $\mathbf{2 9 \%}$ & $\mathbf{1 4 \%}$ \\
\hline ENTRENADORS & $31 \%$ & $\mathbf{5 4 \%}$ & $\mathbf{1 5 \%}$ \\
\hline
\end{tabular}

Font: elaboració pròpia a partir de les dades facilitades per l’associació EE.EE. 613 (any 2012).

Açò fa necessari una formació bàsica dels voluntaris, a fi de dotar-los dels coneixements necessaris perquè puguen reflexionar sobre la situació social del seu barri, i la importància de participar i colllaborar, així com d'oferir un marc d'oportunitats per als infants i adolescents del seu barri.

Atenent a això, un dels objectius de l'entitat és la Formació i motivació del voluntariat en principis $i$ valors coeducatius, integradors, empàtics i participatius; per tal d'això es realitzen xerrades i cursos, amb la colllaboració de tècnics experts tant en matèria esportiva com social, per a preparar els voluntaris. Aquestes es fan amb la xarxa de recursos comunitaris, és a dir Serveis Socials (prevenció en drogodependències), Gabinet Psicopedagògic Escolar (pautes d'ensenyament), Formació i Inserció Laboral (Tècnics Municipals), Centres Escolars (formació esportiva), etc. 
A més, amb l'objecte de motivar els voluntaris, $\mathrm{i}$ oferir una possibilitat de continuïtat als joves majors de 16 anys, que deixen de pertànyer a l'associació al no existir pràcticament competicions en què participar en eixes edats, s'ha dissenyat un projecte per a treballar amb els joves majors de 16 anys, i els monitors voluntaris, mitjançant la creació d'un equip de futbol 11 per a participar en les lligues amateurs. Amb això, es treballen directament dos aspectes: la continuïtat dels joves com a jugadors de les EE.EE 613, i la motivació dels voluntaris al permetre'ls jugar en un equip amb el nom de la seua entitat i del seu barri. A més, açò serveix com un punt de trobada entre els voluntaris de l'associació, al marge de les activitats que comporten el seu compromís de voluntari amb ella.

Estratègia III. Incorporació en el teixit social del municipi de Burjassot, és a dir en la seua realitat local.

A finals de la dècada dels huitanta, Castells (1995) ens va explicar com la globalització del món implicava, de forma paradoxal, un enfortiment d'allò local com a única resposta viable de la ciutadania davant de la pèrdua de control de les seues pròpies vides: local enfront del global. Allò local, concebut des de la proximitat del territori, aferrat a la identitat pròpia, com a veïns, membres d'una cultura, d'una ètnica, d'una nació, i per tant amb gran potencialitat inclusiva.

Una de les estratègies fonamentals per a la inclusió social dels territoris desfavorits és la integració amb els seus barris limítrofs i la plena participació i acceptació de la resta del municipi. En aquest sentit és necessari treballar la integració des de dins a fora i des de fora a dins, per tant les dificultats estan en ambdós costats.

En el cas de les EE.EE. 613, aquesta integració es treballa des de dos fronts, l'esportiu i un altre, més vinculat a la coordinació amb els recursos del territori. Esportivament l'entitat porta en marxa dos actuacions, amb les sues activitats concretes. 
Quadre 3. Actuacions, finalitats i activitats de les EE.EE. 613.

\begin{tabular}{|c|c|c|}
\hline ACTUACIONS & FINALITAT & ACTIVITATS \\
\hline $\begin{array}{l}\text { Participació en les } \\
\text { competicions d'esport } \\
\text { escolar a nivell municipal, } \\
\text { provincial i autonòmic. }\end{array}$ & $\begin{array}{l}\text { Integració en les } \\
\text { competicions esportives } \\
\text { escolars organitzades, } \\
\text { donant així a conèixer } \\
\text { la associació i afavorir la } \\
\text { seua normalització. }\end{array}$ & $\begin{array}{l}\text { Jocs Esportius de la } C V \text {, cada temporada des } \\
\text { de la Generalitat Valenciana s'organitza } \\
\text { les competicions de l'esport escolar de la } \\
\text { comunitat en les diferents disciplines. } \\
\text { Olimpiades escolars municipals, organitzades } \\
\text { anualment pel departament d'esports del } \\
\text { M.I. Ajuntament de Burjassot per a la } \\
\text { finalització de la temporada escolar, i on } \\
\text { participen totes les entitats esportives del } \\
\text { municipi. }\end{array}$ \\
\hline $\begin{array}{l}\text { Organització de tornejos } \\
\text { propis. }\end{array}$ & $\begin{array}{l}\text { Aconseguir que la resta de } \\
\text { Burjassot i de municipis } \\
\text { limítrofs vaja al BAP } 613 \\
\text { i es fracture l'ailllament } \\
\text { social. }\end{array}$ & $\begin{array}{l}\text { Torneig escolar } 613 \text { vivendes, s'inviten } \\
\text { a participar als equips de Burjassot i } \\
\text { municipis limítrofs que també participen } \\
\text { en la lliga escolar i es realitza un torneig } \\
\text { que dura dos setmanes. } \\
24 \text { bores de futbol sala on s'invita a } \\
\text { participar a equips de futbol sala amateurs. } \\
\text { Torneig mixt i intergeneracional de petanca } \\
613 \text { vivendes, la petanca és una activitat } \\
\text { molt estesa en el barri i en la resta del } \\
\text { municipi, i aquest torneig és un bon punt } \\
\text { de trobada per a unir-se i donar a conèixer } \\
\text { a l'associació. }\end{array}$ \\
\hline
\end{tabular}

Font: elaboració pròpia a partir de les dades facilitades per l’associació EE.EE. 613 (any 2012).

En el que respecta a la coordinació amb el recursos del territori, hem de tenir en compte els perfils dels infants i joves amb els que intervé l'associació, que ja hem esmentat en punts anteriors; el que fa necessari una coordinació tant al departament de serveis socials del municipi com amb els centres educatius que treballen amb els infants i adolescents del BAP 613. 
Quadre 3-Bis. Actuacions, finalitats i activitats de les EE.EE. 613.

\begin{tabular}{|c|c|c|}
\hline ACTUACIONS & FINALITAT & ACTIVITATS \\
\hline $\begin{array}{l}\text { Reunions amb el } \\
\text { departament de Servicis } \\
\text { Socials i centres educatius. }\end{array}$ & $\begin{array}{l}\text { Treballar coordinadament } \\
\text { amb els recursos que } \\
\text { intervenen amb els } \\
\text { menors, a fi de poder } \\
\text { abordar els menors d'una } \\
\text { forma integral. }\end{array}$ & $\begin{array}{l}\text { Reunions trimestrals amb el centre educatiu } \\
\text { CAES (Centre d'Atenció Especial) } \\
\text { Reunions amb el programa de mesures } \\
\text { judicials en mig obert } \\
\text { Reunions amb el programa d'absentisme } \\
\text { escolar } \\
\text { Comissió mixta del BAP } 613 \\
\text { Subcomissió educativa municipal }\end{array}$ \\
\hline $\begin{array}{l}\text { Reunions amb l'entramat } \\
\text { associatiu del BAP } 613 \text {. }\end{array}$ & $\begin{array}{l}\text { El teixit associatiu del } \\
\text { BAP } 613 \text { és prou ampli, } \\
\text { existint un important } \\
\text { nombre d'associacions } \\
\text { en ell, dotze en total. } \\
\text { Per això, consideren } \\
\text { important la coordinació } \\
\text { amb les mateixes, atenent } \\
\text { que totes treballen per un } \\
\text { objectiu comú, la millora } \\
\text { del seu barri. }\end{array}$ & $\begin{array}{l}\text { Reunions periòdiques amb les diferents } \\
\text { associacions del BAP 613, en què es } \\
\text { comuniquen futurs esdeveniments, } \\
\text { accions, i sofereixen col-laboració i } \\
\text { cooperació en les activitats a realitzar. }\end{array}$ \\
\hline
\end{tabular}

Font: elaboració pròpia a partir de les dades facilitades per l'associació EE.EE. 613 (any 2012).

\section{Estratègia IV. Treballar des de l'acollida, l'acompanyament i l'autonomia.}

Segons Pérez Eransus (2004:102) “... acompanyar és avançar al costat de l’altre, compartir un projecte comú...", diferenciant-lo del seguiment, perquè en aquest, l'usuari és un objecte pacient, i el professional qui l'observa, vigila i controla. En canvi, l'acompanyament parteix de la responsabilitat de l'usuari en intentar d'organitzar la seua pròpia estratègia, d'utilitzar els recursos que hi ha al seu abast d'una forma eficaç; però també parteix de la constatació de les dificultats que va a trobar-se per fer-lo.

En aquest sentit des del departament de Serveis Socials de l'Ajuntament de Burjassot s'ha acompanyat a l'entitat, s'han donat suport, des del respecte i promovent cada vegada més la seua autonomia política, és a dir és una entitat que com qualsevol altra ha de prendre les seus decisions filosòfiques, de principis i valors, d'estratègia de relació amb la resta d'actors polítics del context i d'intervenció. Als primers anys es gestionava 
com un programa propi de prevenció i inserció social, posteriorment s'acompanya en les decisions del dia a dia i avui s'assessora i ajuda en els processos burocràtics, sol-licituds de subvencions per al finançament de l'entitat, problemes amb institucions, etc. Des de l'acollida inicial, es passà a l'acompanyament i es treballa per l'autonomia definitiva, ja que és l'objectiu final de qualsevol intervenció comunitària, coherent amb la finalitat de les Escoles Esportives 613 Vivendes: Dotar als infants, adolescents i joves, voluntaris $i$ veïns d'una consciència de la situació d'exclusió social en què es troba el barri, i proporcionar eines per a la seua transformació.

\section{Conclusions i Reflexions}

Des de la seua creació en 1994 fins a l'actualitat, les EE.EE 613 han passat per molts moments, de bonança, de precarietat, de ressorgiment, de reformulació...adaptant-se en cada moment a la situació econòmica i social regnant. Precisament, el ser una entitat de proximitat, li ha permès la flexibilitat necessària per a garantir la seua continuïtat. Les EE.EE 613 després de dinou anys han generat una imatge positiva en la qual es troben identificats els infants i adolescents del barri, mitjançant l'entitat han visitat tots els barris del municipi, altres municipis i províncies havent guanyat competicions i fent que el seu barri siga conegut no tan sols per allò negatiu sinó per una imatge positiva.

La intervenció mitjançant l'esport de forma sistemàtica en barris desfavorits i amb col·lectius en situació d'exclusió social, es mostra amb gran èxit participatiu i amb gran capacitat de permetre trencar barreres d'aillament social que es produeixen en aquests barris, de generar percepció positiva d'un mateix i capacitat d'intervenir en el seu futur individual i collectiu, ja que la participació suposa empoderament en el sentit de què les persones arriben a ser capaces de prendre el control de les seues circumstàncies i conquerir objectius, així com de treballar per a la millora de la seua qualitat de vida (Bates i Davis, 2004).

Les EE.EE 613 desenvolupen un programa global i integral on es treballa amb els infants $\mathrm{i}$ adolescents, amb els monitors, amb la Junta Directiva i amb la comunitat, on el treball en xarxa en el dia a dia amb altres entitats i professionals del terreny millora els resultats i genera oportunitats per a totes les entitats: l'estratègia és guanyar-guanyar. 
L'espai local es configura com un espai privilegiat on desenvolupar estratègies d'intervenció participatives que propicien la inclusió social. És un espai on és possible el reconeixement de les persones, els interessos mutus i el desenvolupament d'estratègies comunitàries.

En el context actual d'augment de la desigualtat es fa necessari cada vegada més projectes que des del compromís ètic acompanyen a les persones i a les seues comunitats en un procés de millora col·lectiva, on es trenque el cercle de l'exclusió i les persones participen del seu procés de desenvolupament i és en aquest espai on el treball social comunitari te un rol fonamental.

\section{Referències bibliogràfiques}

Atkinson, R. y Kintrea, K. (2001): "Disentangling Area Effects: Evidence from deprived and non-deprived neighbourhood Effects and Cultural Exclusion”. Urban Studies, 39, 85-93.

Balibrea, E.; Santos, A. y Lerma, I. (2002): "Un estudio exploratorio: actividad física, deporte e inserción social de jóvenes en barrios desfavorecidos". Apunts: Educación física y deportes, 69, 106-111.

Bates, P. y Davis, F. A. (2004): "Social capital, social inclusion and services for people with learning disabilities". Disability and Society, 19 (3), 195-207.

Brooks-Gunn, J. Ducan, G.J., Klebanov, P.K. y Sealand, N. (1993): “Do neighbourhoods affect child and adolescent development?" American Journal Sociology, 99, 353-395.

Bourdieu, P. (1999). La miseria del mundo. Madrid: Akal.

Castel, R. (1997). La metamorfosis de la cuestión social. Una crónica del asalariado. Barcelona: Paidós.

Castells, M. (1995). La ciudad informacional. Madrid: Alianza.

Comisión Europea para el Deporte (1998). Evolución y perspectivas de la acción comunitaria en el Deporte. Bruselas: Comisión Europea.

Comisión de las Comunidades Europeas (2007). Libro blanco sobre el deporte. Bruselas: Comisión Europea. 
Decreto 157/1988, de 11 de octubre, del Consell de la Generalitat Valenciana, por el que se establece el Plan Conjunto de Actuación de Barrios de Acción Preferente. (1988) Diari Oficial de la Generalitat Valenciana. València.

Fernández Gavira, J. (2008): "Experiencias europeas de inclusión a través de la actividad física y deportiva”. Ponencia presentada en el IV Congreso Internacional y XXV Congreso Nacional de Educación Física, Cordoba, 2, 3, 4 y 5 de abril.

Foessa (2013). Análisis y perspectivas 2013. Desigualdad y derechos sociales. Madrid: Fundación Foessa.

Freire, P. (2004). Pedagogía de la autonomía. México: Siglo XXI.

Freire, P. (2005). Pedagogía del oprimido. México: Siglo XXI.

Hellison, D. (1995). Teaching responsability through physical activity. Champaing, II: Human Kinetics.

Hérin, R. (2008): “Violencias en las periferias urbanas francesas. Los disturbios del otoño de 2005”. Scripta Nova, 96, 270-298.

Jenks, C. y Mayer, S.E. (1990): "The social consequences of growing up in a poor neighbourhood"; en MC Geary, M. (ed). Inmer-city poverty in the United States. Nacional Academy Press. Washington

Jiménez, P.J. y Durán, L.J. (2005): "Actividad física y deporte en jóvenes en riesgo: educación en valores”. Apunts: Educación física y deportes, 80, 13-19.

Marchioni, M. (1989). Planificación social y organización de la comunidad: alternativas avanzadas a la crisis. Madrid: Popular.

Maza, G (coor.) (2009). Actividad física y deporte para la inclusión social: inmigración. Plan integral para la actividad física y el deporte, versión 1. Consejo superior de deportes. España. Monje, M. y Uceda-Maza, F.X. (2003): "El barrio de Acción Preferente “613 Viviendas” de Burjassot: El proceso de normalización de viviendas en un Barrio Desfavorecido", en Oteixa, V. Un lugar para vivir. Experiencias de exclusión residencial y de cómo salir de ellas en el Estado Español. Pamplona: Universidad Pública de Navarra.

Leal, E. (2009):"La investigación acción participación, un aporte al conocimiento y a la transformación de Latinoamérica, en permanente movimiento. Investigación, 67 (33), 13-34.

Muñoz, A. J. (2005):"L'activitat física i l'esport com a mitjà d'integració social i transmissió de valors a joves socialment desfavorits". Electrónica d'Investigació i Innovació Educativa i Socioeducativa, 2 (2), 19-38. 
Musterd, S.; Murie, A. y Kesteloot, C. (eds). (2006). Neighbourhoods of poverty: Urban social exclusion and integration in Europe. Palgrave: Londres.

Pardo, R. (2008). La transmisión de valores a jóvenes socialmente desfavorecidos a través de la actividad física y el deporte. Estudio múltiple de casos: Getafe, L'Aquila y Los Ángeles. Madrid: Universidad Politécnica de Madrid.

Paugam, S. (2007). Las formas elementales de la pobreza. Madrid: Alianza editorial.

Pérez Cosin, J.V. y Uceda-Maza, F.X. (2009): “Aproximación teórica a los adolescentes en conflicto con la ley: paradigmas y modelos”. Servicios Sociales y Politica Social, 87, 71-92.

Pérez Eransus, B. (2004): "El acompañamiento social como herramienta de lucha contra la exclusión social”. Documentación Social, 135, 89-107.

Santos, A; Castro, R.M.; Balibrea, E.; López, A. y Arango, L.V. (2004). Mujeres en forma contra la exclusión. Dirección General de la Mujer. València: Generalitat Valenciana.

Subirats, J. (dir.); Obradors, A.; García, P. y Canal, R. (2010). Ciudadanía e Inclusión Social. El tercer sector y las politicas públicas de acción social. Barcelona: Fundació Esplai.

Úcar, X. (2002): “Medio siglo de Animación Sociocultural en España: balance y perspectiva”. Iberoamericana de Educación, 51, 1-22.

Uceda-Maza, F. X. (2012). Adolescentes en conflicto con la ley. Una aproximación comunitaria: Trayectorias, escenarios e itinerarios. Tesis Doctoral. València: Universitat de València. Wacquant, L.J. (2007). Los condenados de la ciudad. Gueto, periferias y Estado., Madrid: Siglo XXI.

Wacquant, L.J. (2008). Urban outcasts: a comparative sociology of advanced marginality. Cambridge, Polity.

Wilson, J. (1987). The Truly Disadvantaged. The Inner City, the underclass, and Public Policy. Illinois: University of Chicago Press.

Zarzuri, R. (2000):"Notas para una aproximación teórica a las nuevas culturas juveniles: las tribus urbanas". Última Década, 13, 81-96. 
Xedagogia i Treball Social

Revista de Ciències Socials Aplicades

Edita: Universitat de Girona

Disseny i maquetació: info@clam.cat · 647427732

Dipòsit Legal: GI.904-2010

ISSN: 2013-9063 